\title{
The Relationship Between Iodine Intake and Serum Thyroglobulin in the General Population
}

\author{
R. BÍLEK ${ }^{1}$, J. ČĚ̌OVSKÁ ${ }^{1}$, V. ZAMRAZIL ${ }^{1}$ \\ ${ }^{1}$ Institute of Endocrinology, Prague, Czech Republic
}

Received June 6, 2014

Accepted November 21, 2014

On-line December 22, 2014

\section{Summary}

The relationship is shown between a concentration of urinary iodine and serum thyroglobulin in population studies carried out on a general population that was randomly selected from the registry of the General Health Insurance Company (individuals aged 6-98 years, 1751 males, 2420 females). The individuals were divided into subgroups with a urinary iodine concentration of $<50,50-99,100-199,200-299$ and $\geq 300 \mu \mathrm{g} / \mathrm{l}$. The mean and median of thyroglobulin were calculated in these subgroups. Tg concentrations were dependent on gender (males $<$ females), age (thyroglobulin increased with age) and statistically significant negative relationship was observed between thyroglobulin and urinary iodine in individuals with urinary iodine $<300 \mu \mathrm{g} / \mathrm{l}$ and the age under 65 years. Upper nonparametric tolerance limits of thyroglobulin in relation to iodine intake were calculated in subgroup of normal individuals $(n=1858$, thyroglobulin, urinary iodine, thyrotropin and free thyroxine were within the normal reference range). Upper limits were dependent on gender and age. The total value of upper limits is $44 \mu \mathrm{g} / \mathrm{l}$; for individuals aged $6-17$ years it is $39.1 \mu \mathrm{g} / \mathrm{l} ; 18-65$ years $=51.4 \mu \mathrm{g} / \mathrm{l}$ and $66-98$ years $=60.6 \mu \mathrm{g} / \mathrm{l}$. In general, thyroglobulin serum concentrations higher than $40 \mu \mathrm{g} / \mathrm{l}$ should be an indicator for determining urinary iodine.

\section{Key words}

Thyroglobulin • Iodine • Population studies • Tolerance limits • Normal individuals

\section{Corresponding author}

R. Bílek, Institute of Endocrinology, Národní 8, 11694 Prague 1, Czech Republic. Fax: +42 224905 325. E-mail: rbilek@endo.cz

\section{Introduction}

About $31 \%$ (1900.9 million) of the world's population is estimated to have insufficient iodine intake, with the most affected World Health Organization regions being South-East Asia and Europe (WHO, UNICEF, ICCIDD 2007). The Czech Republic belongs historically to the area of iodine deficiency; however, since the year 2000 the iodine nutrition has not been a serious public health problem (Zamrazil et al. 2004). The recommended daily intake of iodine should be $90 \mu \mathrm{g}$ for preschool children ( 0 to 59 months), $120 \mu \mathrm{g}$ for schoolchildren (6 to 12 years), $150 \mu \mathrm{g}$ for adolescents (above 12 years) and adults and $250 \mu \mathrm{g}$ for pregnant and lactating women (WHO, UNICEF, ICCIDD 2007). Several indicators are used to assess the iodine status of a population: thyroid volume, urinary iodine (UI) and the blood constituents, thyrotropin (TSH), and thyroglobulin (Tg) (WHO 2004). A major indicator corresponding to iodine nutrition and reflecting recent changes in iodine intake in period of days is concentration of iodine in urine. According to World Health Organization (WHO), United Nations Children's Fund (UNICEF) and International Council for Control of Iodine Deficiency Disorders (ICCIDD), urinary iodine below $20 \mu \mathrm{g} / 1$ denotes severe iodine deficiency, between 20-49 moderate, between 50-99 mild iodine deficiency, UI between 100-199 is adequate iodine intake, UI between 200-299 more than adequate, and UI more than $300 \mu \mathrm{g} / \mathrm{l}$ is excessive iodine intake (WHO, UNICEF, ICCIDD 2007, WHO, UNICEF, ICCIDD 2001). UI concentrations of pregnant women under $150 \mu \mathrm{g} / \mathrm{l}$ indicate an insufficient iodine intake, between 150-249 is

PHYSIOLOGICAL RESEARCH • ISSN 0862-8408 (print) • ISSN 1802-9973 (online)

(C) 2015 Institute of Physiology v.v.i., Academy of Sciences of the Czech Republic, Prague, Czech Republic

Fax +420 241062 164, e-mail: physres@biomed.cas.cz, www.biomed.cas.cz/physiolres 
adequate, between $250-499$ is above the required level and over $500 \mu \mathrm{g} / \mathrm{l}$ is excessive iodine intake (WHO, UNICEF, ICCIDD 2007). Median urinary iodine concentration of $100 \mu \mathrm{g} / \mathrm{l}$ is adequate iodine intake for lactating women and children below 2 years of age (WHO, UNICEF, ICCIDD 2007).

Thyroid volumes reflect a population's history of iodine nutrition, but not its present iodine status (Zimmermann 2004). Thyroid volume may not return to its normal size for months or years after an iodine deficiency correction (Delange et al. 2001), thus it is not a good indicator of iodine deficiency disorders after the introduction of iodized table salt. Iodine deficiency lowers circulating $\mathrm{T} 4$ and raises the serum TSH, so that iodine-deficient populations generally have higher serum TSH concentrations than do iodine-sufficient groups, but the difference is not great and much overlap occurs between individual TSH values. Therefore, the blood TSH concentration in school-age children and adults is not recommended for routine use as an indicator of iodine intake (WHO, UNICEF, ICCIDD 2001).

Thyroglobulin ( $\mathrm{Tg}$ ) may be a promising functional biomarker of both iodine deficiency and excess (Zimmermann et al. 2013). Thyroglobulin originates only in the thyroid gland where the synthesis of thyroid hormones is involved. It is the major iodoglycoprotein of the thyroid gland (molecular weight of soluble dimer about $660 \mathrm{kDa}, \quad 0.1-2.0 \%$ iodine; $8-10 \%$ total carbohydrate with galactose, mannose, fucose, $\mathrm{N}$-acetyl glucosamine and sialic acid residues (Venkatesh and Deshpande 1999), which consists of two identical subunits (homodimer), and belongs to the type B carboxylesterase/lipase family (Park and Arvan 2004). The serum Tg concentrations primarily reflect three factors: a) the mass of differentiated thyroid tissue present; b) any physical damage to or inflammation of the thyroid gland; and c) the magnitude of thyrotropin receptor stimulation (Spencer et al. 1996). The thyroid hyperplasia and goitre characteristic of iodine deficiency increases serum $\mathrm{Tg}$ levels, and, in this setting, the concentration of serum $\mathrm{Tg}$ reflects iodine nutrition over a period of months or years (WHO, UNICEF, ICCIDD 2007).

WHO proposed in 1994 that a median $\mathrm{Tg}$ concentration of less than $10 \mu \mathrm{g} / \mathrm{l}$ in a population indicated iodine sufficiency (WHO, UNICEF, ICCIDD 1994). The value of thyroglobulin as an indicator of global IDD status has not yet to be fully explored (WHO 2004), but the results from population studies show that thyroglobulin seems to be a valuable indicator of thyroid status in respect to its sensitivity to recent changes in iodine nutrition (Benmiloud et al. 1994, Knudsen et al. 2001, European Commission, Scientific Committee on Food 2002, Zimmermann 2004). The main problem is the specification of Tg cut-off value corresponding to various levels of iodine intake. The use of $\mathrm{Tg}$ for monitoring iodine status is limited by a large interassay variability and a lack of reference data for $\mathrm{Tg}$ in healthy, iodinesufficient individuals (Zimmermann et al. 2006). In iodine-deficient areas the serum $\mathrm{Tg}$ concentration is elevated due to TSH hyperstimulation or thyroid hyperplasia (Zimmermann et al. 2006). Serum thyroglobulin and urinary iodine concentration are the most appropriate indicators of iodine status and thyroid function under conditions of increasing iodine supply (van den Briel et al. 2001), because thyroid volume, thyroid nodularity or iodine excretion had close associations to serum $\mathrm{Tg}$ (Knudsen et al. 2001). Significant inverse correlations were found for relationships between measures of urinary iodide excretion and serum thyroglobulin (Thomson et al. 2001, Simsek et al. 2003, Skeaff et al. 2012, Raverot et al. 2012). For example, Buchinger et al. (1997) have shown that the mean serum thyroglobulin of 2311 untreated euthyroid patients decreased progressively as the urinary iodine concentration rose, but that this change did not reach statistical significance. In a cross-sectional study in primary schools in 12 countries with children 6 to 12 years of age $(n=2512)$ it was found that, over a range of iodine intakes from severely deficient to excessive, Tg concentrations showed a clear U-shaped curve (Zimmermann et al. 2013). According to the authors Zimmermann et al. (2006, 2013), median values of $\mathrm{Tg}$ in dried whole blood spots between 13 and $40 \mu \mathrm{g} / \mathrm{l}$ indicate iodine sufficiency in the population of 5 to 14 year-old children. The question is if this reference range can be used for other groups in the population.

Serum $\mathrm{Tg}$ is currently measured by immunoassay, and $\mathrm{Tg}$ belongs among the difficult serum assays in current routine diagnostic due to the inhomogeneity of the large $\mathrm{Tg}$ molecule, where various isoforms of $\mathrm{Tg}$ exist with differences both in the primary structure and iodine or carbohydrate content. These factors determine the three-dimensional conformation of the molecule, and thus they can reduce the epitopes important for immunoanalytical interactions. In addition, the presence of circulating autoantibodies against Tg may substantially interfere in determining serum $\mathrm{Tg}$, and these 
autoantibodies are an important limitation concerning both the precision and accuracy of immunoanalytically measured serum $\mathrm{Tg}$, especially if immunometric techniques are used (false-decreased results, Giovanella and Ceriani 2011). Competitive radioimmunoassay seems to be more resistant to circulating autoantibodies against Tg (Spencer et al. 2005). Nevertheless, the reduced availability of tracer (thyroglobulin labelled with radioiodine) due to binding to autoantibody may lead to false-positive interference in competitive radioimmunoassays. More than adequate iodine intake (Teng et al. 2011) or iodization program (Bülow Pedersen et al. 2011) was associated with an increase in the prevalence of autoantibodies against $\mathrm{Tg}$. Heterophilic antibodies also interfere in $\mathrm{Tg}$ assays and generally result in false elevations of Tg (Preissner et al. 2003, Clark and Franklyn 2012), but treatment using heterophile-blocking agents prevented the potential impact of heterophilic antibodies on $\mathrm{Tg}$ analysis (Giovanella et al. 2009). A collaborative effort, sponsored by the Community Bureau of Reference of the Commission of the European Communities, produced a Tg standard CRM-457 (Feldt-Rasmussen et al. 1996a,b). The applications of this serum $\mathrm{Tg}$ reference material can improve the interassay variability (Zimmermann et al. 2006), but in respect to the complicated three-dimensional structure of $\mathrm{Tg}$ and the various $\mathrm{Tg}$ isoforms, the standardization of antibodies used to determine circulating $\mathrm{Tg}$ can be a more important step for obtaining the comparable results across many commercially available $\mathrm{Tg}$ assays (Bilek et al. 2009). The application of CRM-457 reduced the interassay coefficient of variations from $47 \%$ to $37 \%$ (Spencer et al. 2005) which means that significant differences among various kits remain.

In the $1960 \mathrm{~s}$ the first hemagglutination techniques were developed to measure $\mathrm{Tg}$ in serum (Torrigiani et al. 1969). More convenient RIA techniques were introduced in the 1970s (Van Herle et al. 1973). Immunoradiometric assays used since the 1980s (Mariotti et al. 1982) improve the functional sensitivity of $\mathrm{Tg}$ from 3-5 $\mathrm{ng} / \mathrm{ml}$ (Schlumberger and Baudin 1998) to less than $1 \mathrm{ng} / \mathrm{ml}$ (Smallridge et al. 2007), and the correlation with previous RIAs was excellent in sera not possessing an interference in the assay (Schlumberger and Baudin 1998). Novel serum Tg assays that use mass spectrometry may avoid the issue of autoantibody interference and other problems with currently available immunoassays for Tg (Hoofnagle and Roth 2013, Kushnir et al. 2013). In the work we presented our results concerning the relationship between the concentration of urinary iodine and serum $\mathrm{Tg}$ in a randomly selected general healthy population.

\section{Materials and Methods}

The concentration of urinary iodine was determined using the alkaline ashing of urine specimens preceding the Sandell-Kolthoff reaction with brucine as a colorimetric marker. Details about the spectrophotometric method were published formerly (Bilek et al. 2005).

Serum Tg was determined in 1997-1999 by the 2-step enzymoimmunometric (ELISA, code EnzymunTest Tg, Boehringer-Mannheim, Germany) sandwich assay (1932 individuals aged 5-96 (30+/-21) years, 819 males, 1113 females) using monoclonal mouse antibodies and streptavidin technology. The standards have been calibrated against the BCR standard CRM 457 (reference range $0-85 \mu \mathrm{g} / \mathrm{l}$ ). From 2000 to 2006 serum $\mathrm{Tg}$ was determined with the 1-step electrochemiluminometric (ECLIA, code 1820834 Elecsys Tg Immunoassay, Roche Diagnostics, Mannheim, Germany) sandwich assay (2239 individuals aged 6-98 (29+/-22) years, 932 males, 1307 females) using monoclonal mouse antibodies and streptavidin technology. The standards have been also calibrated against BCR standard CRM 457 (reference range 0-85 $\mu \mathrm{g} / \mathrm{l})$. A linear regression of Elecsys $\mathrm{Tg}(\mathrm{Y})$ with Enzymun-Test Tg (X) using 98 clinical samples gave the following correlations according to the Roche information in the package insert: $\mathrm{Y}=-3.20+1.02 \mathrm{X}$, correlation coefficient $\mathrm{r}=0.995$.

\section{Human subjects}

Basal concentration of urinary iodine and serum $\mathrm{Tg}$ were determined in the general healthy population of 4171 randomly selected individuals from the registry of the General Health Insurance Company aged 5-98 (30+/-22) years (1751 males, 2420 females, total population). This population study was conducted in 1997-2006 in the Czech Republic. All individuals included in the study were in addition to biological sampling also examined by an endocrinologist. In $87.2 \%$ of total population described as normal population on the basis of laboratory diagnostics and medical examination ( $89.7 \%$ of males, $85.5 \%$ of females) was found simultaneously measured serum TSH and FT4 in reference ranges. Subclinical hypothyroidism was 
observed in $5.0 \%$, hypothyroxinemia in $4.4 \%$, clinical hypothyroidism in $1.6 \%$, subclinical hyperthyroidism in $0.8 \%$, clinical hyperthyroidism in $0.4 \%$, hyperthyroxinemia in $0.4 \%$, central hyperthyroidism in $0.1 \%$, central hypothyroidism in $0.1 \%$ of total population and $0.1 \%$ of subjects were missing some of TSH or FT4 determination. The investigation was approved by the local ethical committee.

\section{Statistical methods}

All statistical calculations (means, standard deviations, medians, frequency distributions, descriptive tables, Mann-Whitney U or Wilcoxon rank-sum test for difference in medians, tolerance intervals) were performed using the statistical computer program NCSS 2004 (Number Cruncher Statistical Systems, Kayville, Utah, USA).

\section{Results}

The individuals were divided into subgroups according to their level of iodine intake, i.e. to the subgroup with urinary iodine concentration $<50$ (moderate iodine deficiency), 50-99 (mild iodine deficiency), 100-199 (adequate iodine intake), 200-299 (more than adequate iodine intake) and $\geq 300$ (excessive iodine intake) $\mu \mathrm{g} I / 1$ of urine. In these subgroups the mean and median of $\mathrm{Tg}$ were calculated. The distribution by age and gender of the total population is shown in Figure 1. Tg values were not distributed normally, therefore nonparametric tests were used for statistical analysis. The mean \pm SD (sample standard deviation) and median values of $\mathrm{Tg}$ were $27.9 \pm 54.8,18.0 \mu \mathrm{g} / \mathrm{l}$ for total population $(\mathrm{n}=4171)$ and $27.4 \pm 53.2,18.3 \mu \mathrm{g} / 1$ for normal population $(n=3639)$. We observed the statistically significant differences $(\mathrm{p}<0.0001)$ of $\mathrm{Tg}$ concentrations between males and females both in total population (males: mean 21.4 \pm 19.3 , median 16.8; females: mean 32.6 \pm 69.7 , median 19.4) and normal population (males: mean 21.5 \pm 19.5 , median 16.9; females: mean 31.8 \pm 68.1 , median 19.8) according to Mann-Whitney U or Wilcoxon rank-sum test for difference in medians. The increased concentrations of $\mathrm{Tg}$ in females existed in all subgroups of subjects with given levels of urinary iodine (i.e. moderate, mild iodine deficiency, adequate, more than adequate and excessive iodine intake). The dependence of Tg values on age and gender in normal population, where both $\mathrm{Tg}$ and UI are in reference ranges, is shown in Table 1 .

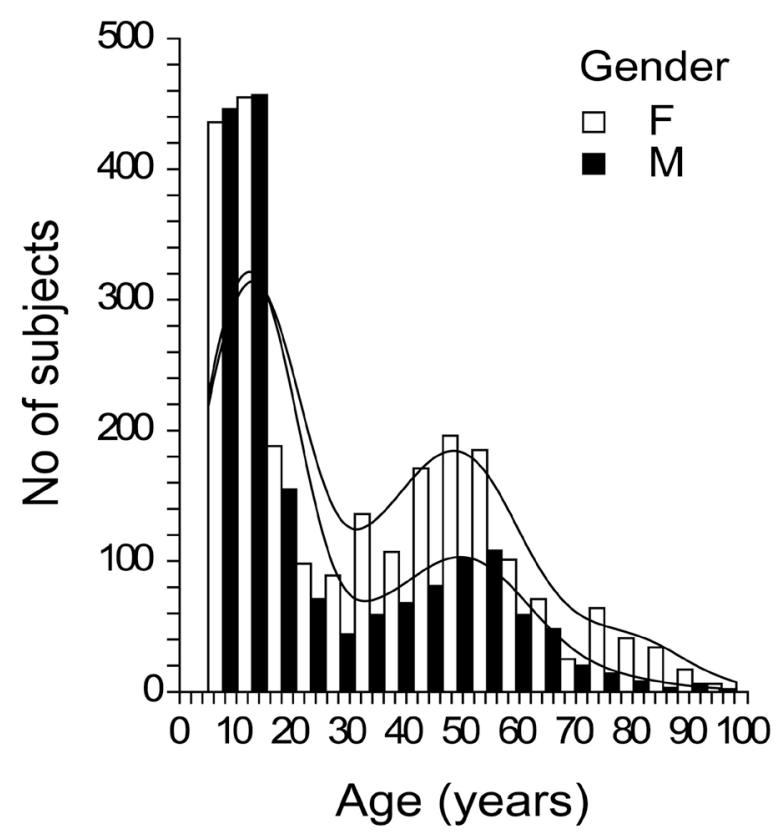

Fig. 1. Histogram of age by gender ( $F$, female; $M$, male) in total populations. Results of population studies concerning the situation of iodine intake conducted in the Czech Republic. 4171 randomly selected individuals (1751 males, 2420 females) participated in this research.

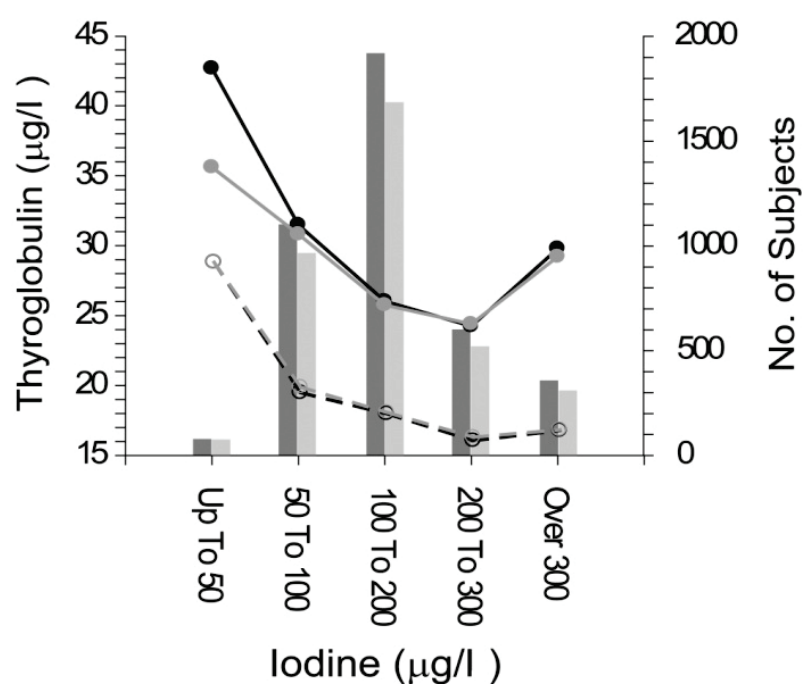

Fig. 2. The relation of mean (solid lines) and median (dashed lines) concentrations of serum thyroglobulin $(\mathrm{Tg})$ on urinary iodine in total (black lines) and normal (shadow lines) populations. Number of subjects is shown as bars. Subjects were divided into subgroups according to their iodine intake and the mean or median of serum thyroglobulin was calculated in these subgroups.

Figure 2 shows that both the mean and median of $\mathrm{Tg}$ decreased in relation to the increase in urinary iodine. However, a slight increase in both mean and median values of $\mathrm{Tg}$ is shown in the subgroup with excessive iodine intake. A partial $U$ shape is shown on the resulting curve. Because the distribution of $\mathrm{Tg}$ values 
was not normal in particular subgroups, it was used the Mann-Whitney U or Wilcoxon Rank-Sum Test for Difference in Medians for evaluation of statistical significant differences of $\mathrm{Tg}$ among particular subgroups based on the concentration of urinary iodine. The differences of $\mathrm{Tg}$ concentrations were statistically significant both in the total and normal population between subgroups of moderate and mild iodine deficiency (total population $\mathrm{p}=0.0047$, normal population $\mathrm{p}=0.0199$ ), between mild iodine deficiency and adequate iodine intake (total population $\mathrm{p}=0.0019$, normal population $\mathrm{p}=0.0010)$, adequate and more than adequate iodine intake (total population $\mathrm{p}=0.0039$, normal population $\mathrm{p}=0.0103$ ), but no significant difference was found between more than adequate and excessive iodine intake (total population $\mathrm{p}=0.2015$, normal population $\mathrm{p}=0.2087$ ). It is clear from Figure 2 that substantially higher mean $\mathrm{Tg}$ values were found in the subgroup of total population with moderate iodine deficiency (mean $\mathrm{Tg}=42.7 \mu \mathrm{g} / \mathrm{l})$, compared to the same subgroup of the normal population (mean $\mathrm{Tg}=35.6 \mu \mathrm{g} / \mathrm{l}$ ). The mean values in other subgroups are nearly the same.

Table 1. Upper tolerance limits of $\mathrm{Tg}$. Upper one-sided $95 \%$ nonparametric tolerance bound of $\mathrm{Tg}$ based on the gender and age in the normal group of subjects where the concentration of $\mathrm{Tg}$ was within the reference range $0-85 \mu \mathrm{g} / \mathrm{l}$ and the values of urinary iodine correspond to the adequate iodine intake with urinary iodine 100-200 $\mu \mathrm{g} / \mathrm{l}$.

\begin{tabular}{lccccc}
\hline Gender & $\begin{array}{c}\text { Age } \\
\text { (years) }\end{array}$ & $\begin{array}{c}\text { Number of } \\
\text { subjects }\end{array}$ & $\begin{array}{c}\text { Mean Tg } \\
(\boldsymbol{\mu g} / \mathbf{l})\end{array}$ & $\begin{array}{c}\text { Median Tg } \\
(\boldsymbol{\mu g} / \mathbf{l})\end{array}$ & $\begin{array}{c}\text { Upper } \\
\text { tolerance limit } \\
\text { of } \mathbf{~ T g}(\boldsymbol{\mu g} / \mathbf{l})\end{array}$ \\
\hline Both & $6-98$ & 1858 & 21.4 & 17.5 & 44.2 \\
Female & $6-98$ & 1038 & 22.6 & 18.3 & 48.4 \\
Male & $6-92$ & 820 & 19.9 & 16.6 & 40.0 \\
& $\mathbf{6 - 1 7}$ & $\mathbf{9 7 0}$ & $\mathbf{1 9 . 5}$ & $\mathbf{1 6 . 3}$ & $\mathbf{3 9 . 1}$ \\
Both & $\mathbf{1 8 - 6 5}$ & $\mathbf{7 9 8}$ & $\mathbf{2 3 . 2}$ & $\mathbf{1 9 . 1}$ & $\mathbf{5 1 . 4}$ \\
& $\mathbf{6 6 - 9 8}$ & $\mathbf{9 0}$ & $\mathbf{2 5 . 7}$ & $\mathbf{1 9 . 8}$ & $\mathbf{6 0 . 6}$ \\
Female & $6-17$ & 471 & 20.1 & 16.9 & 40.6 \\
& $18-65$ & 504 & 24.3 & 19.8 & 53.8 \\
Male & $66-98$ & 63 & 27.7 & 22.7 & 73.4 \\
& $6-17$ & 499 & 18.9 & 15.9 & 38.6 \\
& $18-65$ & 294 & 21.5 & 17.7 & 49.2 \\
& $66-92$ & 27 & 21.1 & 18.7 & 60.3 \\
\hline
\end{tabular}

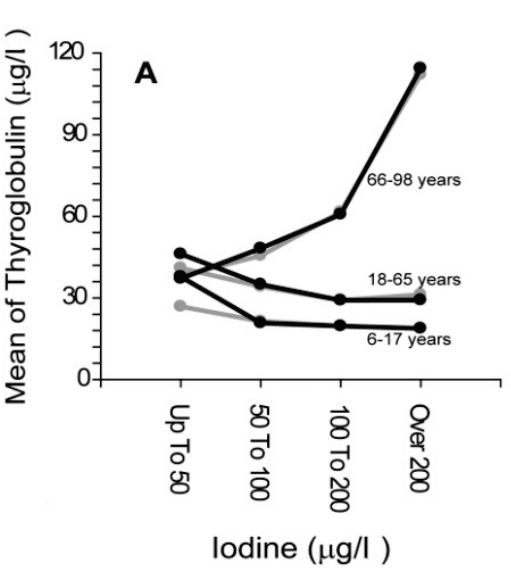

The influence of age on the mean and median values of $\mathrm{Tg}$ in subgroups of total or normal population according to their iodine intake is shown in Figure 3.

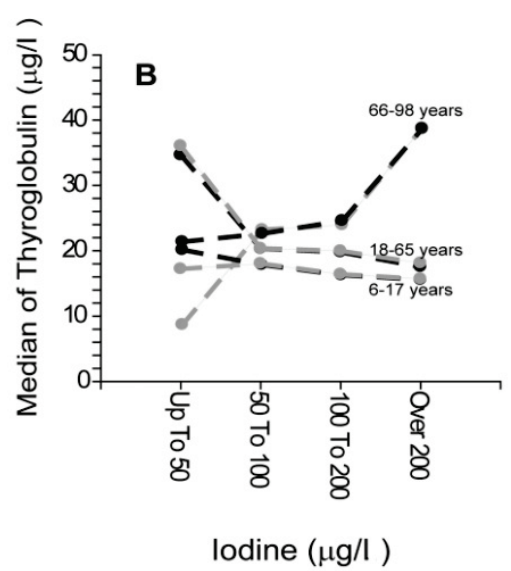

Fig. 3. The influence of age on the relation between mean ( $\mathbf{A}$, solid lines) and median (B, dashed lines) concentrations of serum thyroglobulin and urinary iodine in total (black lines) and normal (shaded lines) populations in subgroups according to their iodine intake. Number of examined subjects was 1961/1738 (total/normal population) for 6-17 years of age, $1832 / 1609$ for $18-65$ years of age and $256 / 193$ for $66-99$ years of age.

lodine $(\mu \mathrm{g} / \mathrm{l})$
The differences of $\mathrm{Tg}$ concentrations were statistically significant $(\mathrm{p}<0.0001)$ both in the total and normal population (Table 1) among subgroups of individuals 
aged 6-17, 18-65 and 66-98 years. The trend of $\mathrm{Tg}$ decrease with the increase of urinary iodine is evident in subjects aged 6-65 years. The situation in individuals over 65 years of age is quite different. There both the mean and median $\mathrm{Tg}$ values increase with the increased iodine intake. The mean Tg values in the subgroup of the elderly with excessive iodine intake were more than $110 \mu \mathrm{g} / \mathrm{l}$, and the median values of Tg were above $38 \mu \mathrm{g} / \mathrm{l}$ both in the normal and total population. The difference of mean or median values of $\mathrm{Tg}$ exists between the total and normal population in the subgroup of moderate iodine deficiency. The difference is higher in individuals aged 6-17 years (total population: mean $\mathrm{Tg}=37.7 \mu \mathrm{g} / \mathrm{l}$, median $\mathrm{Tg}=20.2 \mu \mathrm{g} / \mathrm{l}$; normal population: mean $\mathrm{Tg}=26.8 \mu \mathrm{g} / \mathrm{l}$, median $\mathrm{Tg}=17.2 \mu \mathrm{g} / \mathrm{l}$ ), in comparison with individuals aged 18-65 years (total population: mean $\mathrm{Tg}=46.1 \mu \mathrm{g} / \mathrm{l}$, median $\mathrm{Tg}=34.7 \mu \mathrm{g} / \mathrm{l} ;$ normal population: mean $\mathrm{Tg}=41.0 \mu \mathrm{g} / \mathrm{l}$, median $\mathrm{Tg}=36.1 \mu \mathrm{g} / \mathrm{l})$.

Upper tolerance limits of $\mathrm{Tg}$ in relationship to iodine intake are shown in Table 1. Limits were calculated from individuals of the normal population, where both the concentration of $\mathrm{Tg}$ and urinary iodine were in normal reference range $(\mathrm{Tg}=0-85 \mu \mathrm{g} / \mathrm{l}$, $\mathrm{UI}=100-200 \mu \mathrm{g} / \mathrm{l})$. If the serum $\mathrm{Tg}$ is higher than the tolerance limits, one of the possible factors is insufficient iodine intake and the evaluation of urinary iodine in these individuals can be recommended. It is evident from Table 1 that the tolerance limits in terms of upper onesided $95 \%$ nonparametric tolerance bound of $\mathrm{Tg}$ are influenced by gender and age. Limits are higher in women than in men and they increase with the age. The total value of tolerance limits is $44 \mu \mathrm{g} / \mathrm{l}$, for individuals aged $6-17$ years the value is $39.1 \mu \mathrm{g} / \mathrm{l}$, $18-65$ years $=51.4 \mu \mathrm{g} / 1$ and $66-98$ years $=60.6 \mu \mathrm{g} / \mathrm{l}$.

\section{Discussion}

Difficulties in the immunoanalytical determinations of $\mathrm{Tg}$ are mainly the prevalence of anti- $\mathrm{Tg}$ autoantibodies and their influence to underestimation (immunometric assays) or overestimation (competititve immunoassays) of $\mathrm{Tg}$ and the large interassays variability. This has made it difficult to establish normal reference ranges and/or cutoffs to distinguish the severity of iodine deficiency (Zimmermann 2009). An analysis of data from the 10 intervention studies showed that $\mathrm{Tg}$ does appear to be a useful marker of iodine status in children and adolescents, but there was little evidence of its usefulness in other groups (infants, adults, postmenopausal women, elderly) and it does not appear to be useful during pregnancy and lactation (Ristic-Medic et al. 2009).

Based on our results, we tried to find answers to some of the issues of $\mathrm{Tg}$ as a marker of iodine supply in the population. We found statistically significant differences of $\mathrm{Tg}$ concentrations between men and women. The mean values of $\mathrm{Tg}$ were about $30 \%$ higher in women than men. Our results are in agreement with the fact that serum $\mathrm{Tg}$ is elevated in subjects with deficient iodine intake. As can be seen in Figures 2 and 3, the increase of urinary iodine is accompanied by a decrease of serum thyroglobulin concentrations. In our examined subjects aged 6-98 years the relationship between a urinary iodine and concentration of $\mathrm{Tg}$ was statistically significant in all subgroups based on iodine intake except for differences between the subgroups of more than adequate and excessive iodine intake. Figures 2 and 3 show that the dependence corresponds to the partial U-shaped curve. Similar results were found for example by Zimmermann et al. $(2006,2013)$. However, as shown in Figure 3, the results are dependent on the age and they are not valid for the population over 65 years of age. In elderly people there was shown only an increase of mean or median values of $\mathrm{Tg}$ with an increase of UI across all subgroups based on iodine intake and in more than adequate to excessive iodine intake the mean and median values were 112 (mean) or 39 (median) $\mu \mathrm{g} / \mathrm{l}$. It is important that, while in the subgroups of mild deficiency to excessive iodine intake in the total and normal population the mean and median values of $\mathrm{Tg}$ are almost the same, they differ in the subgroup corresponding to a moderate iodine deficiency. From Figure 3 it is clear comparing the normal and total population that an increase of $\mathrm{Tg}$ was higher in children and in people over 65 years, while in adults aged 18-65 years, the difference was not so significant. In other words, it is possible to say that children and elderly people with any thyroid disorders are more sensitive to iodine deficiency than adults.

The mean or median values of $\mathrm{Tg}$ was found nearly 2 times higher in our study than was published for the normal population with sufficient iodine intake by WHO (WHO, UNICEF, ICCIDD 1994), Spencer and Wang (1995) or Vejbjerg et al. (2009), which states that a median serum $\mathrm{Tg}$ in the population less than $10 \mu \mathrm{g} / \mathrm{l}$ is a marker of iodine sufficiency using the immunoluminometric assay (Lumitest, Brahms, Germany). The problem with cut-off value of $\mathrm{Tg}$ in 
relationship with iodine nutrition is that for example serum $\mathrm{Tg}$ normal reference values in a group of healthy subjects (209 males, 229 non-pregnant females, age $34.7 \pm 13.1$ years) were determined in the range of $1.40-29.2 \mathrm{ng} / \mathrm{ml}$ (males) or $1.50-38.5 \mathrm{ng} / \mathrm{ml}$ (females) using Beckman Coulter UniCel DxI 800 immunoanalyzer (Giovanella et al. 2012). However, the influence of iodine intake in this group of subjects is not known and, on the other hand, median values of $\mathrm{Tg}$ between 13 and $40 \mu \mathrm{g} / \mathrm{l}$ determine the iodine sufficiency in the population (Zimmermann et al. 2013). The tolerance limits of $\mathrm{Tg}$, whose excessive values should be considered, along with iodine deficiency, as one of the factors that increase $\mathrm{Tg}$, are listed in Table 1. The limits were calculated from the values of normal population, where both the UI and $\mathrm{Tg}$ were inside the reference range. Our results suggest that the limits in the term of upper one-sided $95 \%$ nonparametric bound of $\mathrm{Tg}$ are dependent on the gender and age. They are higher in women than men and they increase with age. The total tolerance limit of $\mathrm{Tg}$ was $44.2 \mu \mathrm{g} / 1$ for the whole normal population with values of $\mathrm{UI}$ and $\mathrm{Tg}$ inside the reference ranges. These limits were $39.1 \mu \mathrm{g} / 1$ for children aged 6-17 years, $51.4 \mu \mathrm{g} / 1$ for adults aged $18-65$ years and $60.6 \mu \mathrm{g} / 1$ for people aged
66-98 years. There is agreement between our results and the results published by the authors Zimmermann et al. (2013) for school children aged 6-12 years $(n=2512)$ where median values of $\mathrm{Tg}$ determined in standardized dried blood spots between 13 and $40 \mu \mathrm{g} / \mathrm{l}$ are indicative of iodine sufficiency.

In conclusion, $\mathrm{Tg}$ seems to be a useful marker of iodine deficiency in a population, where thyroid diseases are not too frequent. Tg values are dependent on gender and age, and our results also show that, under conditions of iodine deficiency, the dietary iodine factor that increases the concentration of $\mathrm{Tg}$ in the circulation is inadequate, and thus directly points to the fact that thyroid disorders are amplified by iodine deficiency. Children and the elderly are more affected in this respect by insufficient iodine supply.

\section{Conflict of Interest}

There is no conflict of interest.

\section{Acknowledgements}

The work was supported by grants IGA NS/9837-4, IGA NT/12336-4 of the Ministry of Health, Czech Republic.

\section{References}

BENMILOUD M, CHAOUKI ML, GUTEKUNST R, TEICHERT HM, WOOD WG, DUNN JT: Oral iodized oil for correcting iodine deficiency: optimal dosing and outcome indicator selection. J Clin Endocrinol Metab 79: 20-24, 1994.

BÍLEK R, ZAMRAZIL V: Thyroglobulin as an indicator of iodine intake. In: Comprehensive Handbook on Iodine: Nutritional, Biochemical, Pathological and Therapeutic Aspects. VR PREEDY, GN BURROW, R WATSON (eds), Academic Press, Oxford, 2009, pp 55-64.

BILEK R, BEDNAR J, ZAMRAZIL V: Spectrophotometric determination of urinary iodine by the Sandell-Kolthoff reaction subsequent to dry alkaline ashing: Results from the Czech Republic in the period 1994-2002. Clin Chem Lab Med 43: 573-580, 2005.

BUCHINGER W, LORENZ-WAWSCHINEK O, SEMLITSCH G, LANGSTEGER W, BINTER G, BONELLI RM, EBER O: Thyrotropin and thyroglobulin as an index of optimal iodine intake: correlation with iodine excretion of 39,913 euthyroid patients. Thyroid 7: 593-597, 1997.

BÜLOW PEDERSEN I, KNUDSEN N, CARLÉ A, VEJBJERG P, JURGENSEN T, PERRILD H, OVESEN L, BANKE RASMUSSEN L, LAURBERG P: A cautious iodization programme bringing iodine intake to a low recommended level is associated with an increase in the prevalence of thyroid autoantibodies in the population. Clin Endocrinol (Oxf) 75: 120-126, 2011.

CLARK P, FRANKLYN J: Can we interpret serum thyroglobulin results? Ann Clin Biochem 49: 313-322, 2012.

DELANGE F, DE BENOIST B, PRETELL E, DUNN JT: Iodine deficiency in the world: where do we stand at the turn of the century? Thyroid 11: 437-447, 2001.

EUROPEAN COMMISSION, SCIENTIFIC COMMITTEE ON FOOD: Opinion of the scientific committee on food on the tolerable upper intake level of iodine. SCF/CS/NUT/UPPLEV/26 Final, Brussels, 2002. 
FELDT-RASMUSSEN U, PROFILIS C, COLINET E, BLACK E, BORNET H, BOURDOUX P, CARAYON P, ERICSSON UB, KOUTRAS DA, LAMAS DE LEON L, DENAYER P, PACINI F, PALUMBO G, SANTOS A, SCHLUMBERGER M, SEIDEL C, VAN HERLE AJ, DE VIJLDER JJ: Human thyroglobulin reference material (CRM 457): 1st Part: Assessment of homogeneity, stability and immunoreactivity. Ann Biol Clin (Paris) 54: 337-342, 1996a.

FELDT-RASMUSSEN U, PROFILIS C, COLINET E, BLACK E, BORNET H, BOURDOUX P, CARAYON P, ERICSSON UB, KOUTRAS DA, LAMAS DE LEON L, DENAYER P, PACINI F, PALUMBO G, SANTOS A, SCHLUMBERGER M, SEIDEL C, VAN HERLE AJ, DE VIJLDER JJ: Human thyroglobulin reference material (CRM 457): 2nd Part: Physicochemical characterization and certification. Ann Biol Clin (Paris) 54: 343-348, $1996 \mathrm{~b}$.

GIOVANELLA L, CERIANI L: Comparison of thyroglobulin antibody interference in first- and second-generation thyroglobulin immunoassays. Clin Chem Lab Med 49: 1025-1027, 2011.

GIOVANELLA L, KELLER F, CERIANI L, TOZZOLI R: Heterophile antibodies may falsely increase or decrease thyroglobulin measurement in patients with differentiated thyroid carcinoma. Clin Chem Lab Med 47: 952-954, 2009.

GIOVANELLA L, IMPERIALI M, FERRARI A, PALUMBO A, FURLANI L, GRAZIANI MS, CASTELLO R: Serum thyroglobulin reference values according to NACB criteria in healthy subjects with normal thyroid ultrasound. Clin Chem Lab Med 50: 891-893, 2012.

HOOFNAGLE AN, ROTH MY: Clinical review: improving the measurement of serum thyroglobulin with mass spectrometry. J Clin Endocrinol Metab 98: 1343-1352, 2013.

KNUDSEN N, BULOW I, JORGENSEN T, PERRILD H, OVESEN L, LAURBERG P: Serum Tg - a sensitive marker of thyroid abnormalities and iodine deficiency in epidemiological studies. $J$ Clin Endocrinol Metab 86: 3599-3603, 2001.

KUSHNIR MM, ROCKWOOD AL, ROBERTS WL, ABRAHAM D, HOOFNAGLE AN, MEIKLE AW: Measurement of thyroglobulin by liquid chromatography-tandem mass spectrometry in serum and plasma in the presence of antithyroglobulin autoantibodies. Clin Chem 59: 982-990, 2013.

MARIOTTI S, CUPINI C, GIANI C, LARI R, ROLLERI E, FALCO A, MARCHISIO M, PINCHERA A: Evaluation of a solid-phase immunoradiometric assay (IRMA) for serum thyroglobulin: effect of anti-thyroglobulin autoantibody. Clin Chim Acta 123: 347-355, 1982.

PARK YN, ARVAN P: The acetylcholinesterase homology region is essential for normal conformational maturation and secretion of thyroglobulin. J Biol Chem 279: 17085-17089, 2004.

PREISSNER CM, O'KANE DJ, SINGH RJ, MORRIS JC, GREBE SK: Phantoms in the assay tube: heterophile antibody interferences in serum thyroglobulin assays. J Clin Endocrinol Metab 88: 3069-3074, 2003.

RAVEROT V, BOURNAUD C, SASSOLAS G, ORGIAZZI J, CLAUSTRAT F, GAUCHERAND P, MELLIER G, CLAUSTRAT B, BORSON-CHAZOT F, ZIMMERMANN M: Pregnant French women living in the Lyon area are iodine deficient and have elevated serum thyroglobulin concentrations. Thyroid 22: 522-528, 2012.

RISTIC-MEDIC D, PISKACKOVA Z, HOOPER L, RUPRICH J, CASGRAIN A, ASHTON K, PAVLOVIC M, GLIBETIC M: Methods of assessment of iodine status in humans: a systematic review. Am J Clin Nutr 89: 2052S-2069S, 2009.

SCHLUMBERGER M, BAUDIN E: Serum thyroglobulin determination in the follow-up of patients with differentiated thyroid carcinoma. Eur J Endocrinol 138: 249-252, 1998.

SIMSEK E, SAFAK A, YAVUZ O, ARAS S, DOGAN S, KOCABAY K: Sensitivity of iodine deficiency indicators and iodine status in Turkey. J Pediatr Endocrinol Metab 16: 197-202, 2003.

SKEAFF SA, THOMSON CD, WILSON N, PARNELL WR: A comprehensive assessment of urinary iodine concentration and thyroid hormones in New Zealand schoolchildren: a cross-sectional study. Nutr J 11: 31, 2012.

SMALLRIDGE RC, MEEK SE, MORGAN MA, GATES GS, FOX TP, GREBE S, FATOURECHI V: Monitoring thyroglobulin in a sensitive immunoassay has comparable sensitivity to recombinant human tsh-stimulated thyroglobulin in follow-up of thyroid cancer patients. J Clin Endocrinol Metab 92: 82-87, 2007. 
SPENCER CA, WANG CC: Thyroglobulin measurement: Techniques, clinical benefits, and pitfalls. Endocrinol Metab Clin North Am 24: 841-863, 1995.

SPENCER CA, TAKEUCHI M, KAZAROSYAN M: Current status and performance goals for serum thyroglobulin assays. Clin Chem 42: 164-173, 1996.

SPENCER CA, BERGOGLIO LM, KAZAROSYAN M, FATEMI S, LOPRESTI JS: Clinical impact of thyroglobulin ( $\mathrm{Tg}$ ) and $\mathrm{Tg}$ autoantibody method differences on the management of patients with differentiated thyroid carcinomas. J Clin Endocrinol Metab 90: 5566-5575, 2005.

TENG X, SHAN Z, CHEN Y, LAI Y, YU J, SHAN L, BAI X, LI Y, LI N, LI Z, WANG S, XING Q, XUE H, ZHU L, HOU X, FAN C, TENG W: More than adequate iodine intake may increase subclinical hypothyroidism and autoimmune thyroiditis: a cross-sectional study based on two Chinese communities with different iodine intake levels. Eur J Endocrinol 164: 943-950, 2011.

THOMSON CD, WOODRUFFE S, COLLS AJ, JOSEPH J, DOYLE TC: Urinary iodine and thyroid status of New Zealand residents. Eur J Clin Nutr 55: 387-392, 2001.

TORRIGIANI G, DONIACH D, ROITT IM: Serum thyroglobulin levels in healthy subjects and in patients with thyroid disease. J Clin Endocrinol Metab 29: 305-314, 1969.

VAN DEN BRIEL T, WEST CE, HAUTVAST JG, VULSMA T, DE VIJLDER JJ, ATEGBO EA: Serum thyroglobulin and urinary iodine concentration are the most appropriate indicators of iodine status and thyroid function under conditions of increasing iodine supply in schoolchildren in Benin. J Nutr 131: 2701-2706, 2001.

VAN HERLE AJ, ULLER RP, MATTHEWS NI, BROWN J: Radioimmunoassay for measurement of thyroglobulin in human serum. J Clin Invest 52: 1320-1327, 1973.

VEJBJERG P, KNUDSEN N, PERRILD H, LAURBERG P, CARLÉ A, PEDERSEN IB, RASMUSSEN LB, OVESEN L, JORGENSEN T: Thyroglobulin as a marker of iodine nutrition status in the general population. Eur J Endocrinol 161: 475-481, 2009.

VENKATESH SG, DESHPANDE V: A comparative review of the structure and biosynthesis of thyroglobulin. Comp Biochem Physiol C Pharmacol Toxicol Endocrinol 122: 13-20, 1999.

WHO: Iodine status worldwide. In: WHO Global Database on Iodine Deficiency. B DE BENOIST, BM ANDERSSON, I EGLI, B TAKKOUCHE, H ALLEN (eds), WHO Department of Nutrition for Health and Development, Geneva, 2004.

WHO, UNICEF, ICCIDD: Indicators for assessing iodine deficiency disorders and their control through salt iodization. WHO/NUT/94.6, Geneva, 1994.

WHO, UNICEF, ICCIDD: Assessment of iodine deficiency disorders and monitoring their elimination: a guide for programme managers. WHO/NHD/01.1, Geneva, 2001.

WHO, UNICEF, ICCIDD: Assessment of iodine deficiency disorders and monitoring their elimination: a guide for programme managers. $3^{\text {rd }}$ ed., WHO, Geneva, 2007.

ZAMRAZIL V, BILEK R, CEROVSKA J, DELANGE F: The elimination of iodine deficiency in the Czech Republic: the steps toward success. Thyroid 14: 49-56, 2004.

ZIMMERMANN MB: Assessing iodine status and monitoring progress of iodized salt programs. $J$ Nutr 134: 1673-1677, 2004.

ZIMMERMANN MB: Iodine deficiency. Endocr Rev 30: 376-408, 2009.

ZIMMERMANN MB, DE BENOIST B, CORIGLIANO S, JOOSTE PL, MOLINARI L, MOOSA K, PRETELL EA, AL-DALLAL ZS, WEI Y, ZU-PEI C, TORRESANI T: Assessment of iodine status using dried blood spot thyroglobulin: development of reference material and establishment of an international reference range in iodine-sufficient children. J Clin Endocrinol Metab 91: 4881-4887, 2006.

ZIMMERMANN MB, AEBERLI I, ANDERSSON M, ASSEY V, YORG JA, JOOSTE P, JUKIÆ T, KARTONO D, KUSIÆ Z, PRETELL E, SAN LUIS TO JR, UNTORO J, TIMMER A: Thyroglobulin is a sensitive measure of both deficient and excess iodine intakes in children and indicates no adverse effects on thyroid function in the UIC range of 100-299 $\mu \mathrm{g} / \mathrm{L}$ : a UNICEF/ICCIDD study group report. J Clin Endocrinol Metab 98: 1271-1280, 2013. 